\title{
Affinity Chromatography of Bovine Trypsin
}

\author{
A RAPID SEPARATION OF BOVINE $\alpha$ - AND $\beta$-TRYPSIN
}

\author{
By G. W. JAMESON and D. T. ELMORE \\ Department of Biochemistry, Medical Biology Centre, Queen's University, \\ Belfast BT9 7BL, N. Ireland, U.K.
}

(Received 19 November 1973)

\begin{abstract}
Affinity adsorbents for bovine trypsin were prepared by covalently coupling $p$-( $p^{\prime}$-aminophenoxypropoxy)benzamidine to cellulose and to agarose. Trypsin binds to both adsorbents at pH 6-8 and is released at low $\mathrm{pH}$ values or in the presence of $n$-butylamine hydrochloride. Pure $\beta$-trypsin may be eluted from crude trypsin bound at $\mathrm{pH} 8.0$ to the cellulose adsorbent by stepwise elution with an acetate buffer, pH5.0. Both $\alpha$ - and $\beta$-trypsin may be isolated by chromatography of crude trypsin on the agarose derivative in an acetate buffer, pH4.0. These two methods for purifying the trypsin are specific to the particular adsorbents. They are rapid and convenient in use. Both methods leave a mixture of the two enzymes bound to the adsorbent and release occurs only at low $\mathrm{pH}$ values. The effects of $\mathrm{pH}$, composition and ionic strength of buffer and other variables on both purification methods are described. Affinity adsorbents of soya-bean trypsin inhibitor and of $N-\alpha-\left(N^{\prime}-\right.$-methyl- $N^{\prime}$-sulphanilyl)sulphanilylagmatine bound to agarose were prepared, but were found to be of limited usefulness in the purification of trypsin.
\end{abstract}

An adsorbent for the affinity chromatography of enzymes is prepared by covalently attaching an enzyme-specific ligand to an insoluble support. Separation of an enzyme from a mixture is commonly achieved by applying a crude enzyme preparation to the column in a buffer chosen so that the desired enzyme binds firmly to the adsorbent while other proteins are unretarded on elution. The bound enzyme is then commonly eluted in a single sharp peak by an abrupt buffer change (Cuatrecasas \& Anfinsen, 1971 a,b; Friedberg, 1971). This technique has been applied to the separation of trypsin from inert protein by using both small and large ligands (Feinstein, 1970a,b; Uren, 1971; Kasai \& Ishii, 1972; Hixson \& Nishikawa, 1973). Bovine trypsin, however, exists in two major forms, $\alpha$-trypsin and $\beta$-trypsin, which have been isolated by chromatography on sulphoethyl-Sephadex (Schroeder \& Shaw, 1968; Berezin et al., 1969). $\beta$-Trypsin has a single polypeptide chain, whereas $\alpha$-trypsin has two chains resulting from an autocatalytic cleavage of the Lys ${ }^{(131)}-S_{\text {Ser }}{ }^{(132)}$ bond. The two enzymes exhibit different kinetic characteristics in their reactions with some synthetic substrates (Hruska et al., 1969; Roberts et al., 1971; Jameson et al., 1973; Roberts \& Elmore, 1974). We report the separation of $\alpha$ - and $\beta$-trypsin by two simple and rapid chromatographic procedures involving no gradients, and the factors that affect the separations have been investigated. A preliminary account of this work has been published (Jameson \& Elmore, 1971). Since this work was completed, a separation of the two forms of trypsin by gradient elution from chicken ovomucoid inhibitor linked to Sepharose has been reported (Robinson et al., 1971).

\section{Experimental}

\section{Materials}

Bovine trypsin (thrice-crystallized, salt-free, freezedried) and bovine $\alpha$-chymotrypsin (thrice-crystallized, salt-free, freeze-dried) were purchased from Worthington Biochemical Corp., Freehold, N.J., U.S.A. Soya-bean trypsin inhibitor (five times crystallized) was obtained from Mann Research Laboratories, New York, N.Y., U.S.A. $p^{\prime}$-Nitrophenyl $p$-guanidinobenzoate hydrochloride was synthesized by the method of Chase \& Shaw (1967) and the corresponding 4-methylumbelliferyl ester hydrochloride was prepared as described by Jameson et al. (1973). $S$-(2-Aminoethyl)- $N$-benzoyl-L-cysteine methyl ester hydrochloride was synthesized by the method of Elmore et al. (1967) and 4-methylumbelliferyl $p$-( $N N N$-trimethylammonium)cinnamate chloride by the method of Jameson et al. (1973). p-( $p^{\prime}-$ Aminophenoxypropoxy)benzamidine as the benzenesulphonate was prepared by a method based on that of Baker \& Erickson (1968), but the yield of the intermediate $p$-hydroxybenzamidine $(66 \%)$ was almost twice that reported by these workers. Dioxan $(150 \mathrm{ml}$ for $0.1 \mathrm{~mol}$ of $p$-cyanophenol) 
replaced chloroform as solvent; reaction with ethanol- $\mathrm{HCl}$ was allowed to proceed for 10 days instead of $18 \mathrm{~h}$; unchanged $p$-cyanophenol was removed by distillation under reduced pressure before reaction with $\mathrm{NH}_{3}$. $p$-Hydroxybenzamidine was isolated as the hydrochloride, m.p. $222-224^{\circ} \mathrm{C}$ [Partridge \& Short (1947) quote m.p. 223-224 ${ }^{\circ} \mathrm{C}$, and the latter was then converted into the benzenesulphonate, m.p. $183-186^{\circ} \mathrm{C}$ [Baker \& Erickson (1968) quote m.p. $180-181^{\circ} \mathrm{C}$; Partridge \& Short (1947) quote m.p. $187^{\circ} \mathrm{C}$. The remainder of the preparation of $p$ - $\left(p^{\prime}\right.$-aminophenoxypropoxy)benzamidine benzenesulphonate was carried out as described by Baker \& Erickson (1968) except that the hydrogenation of the $p$-nitro precursor was carried out in the presence of $10 \%$ palladium on charcoal at atmospheric pressure and the product was crystallized twice from acetonitrile by treatment with activated charcoal. The product had m.p. $180-182^{\circ} \mathrm{C}$ [Baker \& Erickson (1968) quote m.p. $173-174^{\circ} \mathrm{C}$. $N N$-Dimethylformamide was purified by fractional distillation from $\mathrm{P}_{2} \mathrm{O}_{5}$. Thionyl chloride was purified by distillation from quinoline followed by distillation from linseed oil. Sepharose $4 B$ and Sepharose 2B were obtained from Pharmacia Fine Chemicals, Uppsala, Sweden, and cellulose powder (Whatman CC31) was purchased from W. and R. Balston Ltd., Maidstone, Kent, U.K.

Sodium $N$-benzyloxycarbonylsulphanilate. Sulphanilic acid $(44.3 \mathrm{~g})$ was dissolved in water $(1000 \mathrm{ml})$ and allowed to react with benzyl chloroformate $(47.0 \mathrm{~g})$ in ether $(200 \mathrm{ml})$ at $\mathrm{pH} 8$ (in a pH-stat) with mechanical stirring. The precipitated solid was filtered off and washed with ether. Another crop was obtained by extracting the filtrate with ether and evaporating the aqueous phase under reduced pressure. The total product $(\mathbf{7 8 \%})$ was recrystallized from methanol; it did not melt below $300^{\circ} \mathrm{C}$ (Found: $\mathrm{C}, 50.8 ; \mathrm{H}, 3.8$. $\mathrm{C}_{14} \mathrm{H}_{12} \mathrm{NNaO}_{5} \mathrm{~S}$ requires $\mathrm{C}, 51.1 ; \mathrm{H}, 3.7 \%$ ).

$N$-Benzyloxycarbonylsulphanilyl chloride. Dry sodium $N$-benzyloxycarbonylsulphanilate $(20.0 \mathrm{~g})$ was dissolved in dry $N N$-dimethylformamide $(20 \mathrm{ml})$, and dry benzene $(200 \mathrm{ml})$ followed by thionyl chloride $(24.0 \mathrm{~g})$ were added. The mixture was stirred for $1 \mathrm{~h}$, poured into an ice-water mixture $(200 \mathrm{ml})$ and then neutralized with $\mathrm{NaHCO}_{3}$. The benzene layer was washed with water $(3 \times 200 \mathrm{ml})$, dried (with $\left.\mathrm{MgSO}_{4}\right)$ and evaporated to dryness under reduced pressure. The residual product $(93 \%)$ had m.p. $111-113^{\circ} \mathrm{C}$, unchanged after recrystallization from benzenelight petroleum (b.p. $60-80^{\circ} \mathrm{C}$ ) (Found: C, 51.5; $\mathrm{H}, 3.9 ; \mathrm{S}, 10.0$. $\mathrm{C}_{14} \mathrm{H}_{12} \mathrm{ClNO}_{4} \mathrm{~S}$ requires $\mathrm{C}, 51.6$; $\mathrm{H}, 3.7 ; \mathrm{S}, 9.8 \%$ ).

Sodium $N-\left(N^{\prime}\right.$-benzyloxycarbonylsulphanilyl $)-N$ methylsulphanilate. $N$-Methylsulphanilic acid $(10.0 \mathrm{~g})$ was dissolved in a mixture of acetonitrile and water $(1: 1, \mathrm{v} / \mathrm{v})$ by neutralizing it with $\mathrm{NaOH}$. A solution of $N$-benzyloxycarbonylsulphanilyl chloride
$(17.4 \mathrm{~g})$ in acetonitrile $(30 \mathrm{ml})$ was added and the reaction mixture was maintained at $\mathrm{pH} 6$ (with a pH-stat) with vigorous mechanical stirring. When the reaction was complete (about $3 \mathrm{~h}$ ), the mixture was evaporated to dryness under reduced pressure and the resulting solid was recrystallized twice from methanol-ether with one treatment with activated charcoal and removal of material insoluble in methanol. The resulting sodium salt $(20.6 \mathrm{~g})$ was a pale-brown solid. One sample was converted into the potassium salt through the free acid. The potassium salt was recrystallized from $N N$-dimethylformamide-ether and then from water. It was dried in vacuo, when it had m.p. $175-178^{\circ} \mathrm{C}$ (decomp.) and was homogeneous by t.l.c. on silica in methanol containing $1 \%(\mathrm{v} / \mathrm{v})$ acetic acid (Found: C, 43.9; $\mathrm{H}$, 4.5. $\mathrm{C}_{21} \mathrm{H}_{19} \mathrm{KN}_{2} \mathrm{O}_{7} \mathrm{~S}_{2}, 3 \mathrm{H}_{2} \mathrm{O}$ requires $\mathrm{C}$, 44.3; $\mathrm{H}, 4.4 \%$ ). Another sample of the sodium salt was converted into the dicyclohexylammonium salt, which was recrystallized twice from methanol-ether and then had m.p. $187-188^{\circ} \mathrm{C}$ and was homogeneous by t.l.c. on silica in methanol containing $1 \%$ (v/v) acetic acid (detected by $I_{2}$ vapour) (Found: C, 59.9; $\mathrm{H}, 6.8 . \mathrm{C}_{33} \mathrm{H}_{43} \mathrm{~N}_{3} \mathrm{O}_{7} \mathrm{~S}_{2}$ requires $\mathrm{C}, 60.2$; $\mathrm{H}, 6.6 \%$ ).

$N-\left(N^{\prime}\right.$ - Benzyloxycarbonylsulphanilyl $)-N$ - methylsulphanilyl chloride. Sodium $N$ - $\left(N^{\prime}\right.$-benzyloxycarbonylsulphanilyl)- $N$-methylsulphanilate $(10.0 \mathrm{~g})$ was suspended in a mixture of dry $N N$-dimethylformamide $(20 \mathrm{ml})$ and dry benzene $(200 \mathrm{ml})$ and treated with thionyl chloride $(20.0 \mathrm{~g})$. The mixture was stirred for $4 \mathrm{~h}$ and poured into a slurry of ice and water $(750 \mathrm{ml})$. The aqueous solution was neutralized with $\mathrm{NaHCO}_{3}$, more benzene $(100 \mathrm{ml})$ was added and the upper phase was separated. The benzene solution was washed with water $(3 \times 300 \mathrm{ml})$, dried (with $\mathrm{MgSO}_{4}$ ) and evaporated under reduced pressure to a small volume. Addition of light petroleum (b.p. $\left.60-80^{\circ} \mathrm{C}\right)$ gave the product $(82 \%)$, which had m.p. $147-148^{\circ} \mathrm{C}$ after recrystallization from benzenelight petroleum (b.p. $60-80^{\circ} \mathrm{C}$ ) and was shown to be homogeneous by t.l.c. on silica in benzene (Found: $\mathrm{C}, 51.9 ; \mathrm{H}, 3.9 ; \mathrm{N}, 5.6 . \mathrm{C}_{21} \mathrm{H}_{19} \mathrm{ClN}_{2} \mathrm{O}_{6} \mathrm{~S}_{2}$ requires C, $51.0 ; \mathrm{H}, 3.9 ; \mathrm{N}, 5.7 \%)$.

$N-\alpha-\left[N^{\prime}-\left(N^{\prime \prime}-\right.\right.$ Benzyloxycarbonylsulphanilyl $)-N^{\prime}-$ methylsulphanilyl]agmatine hydrochloride. Agmatine sulphate was converted into the dihydrochloride by passage through a column of Dowex $1\left(\mathrm{X}-4 ; \mathrm{Cl}^{-}\right.$ form) ion-exchange resin (Bio-Rad Laboratories, Richmond, Calif., U.S.A.). $\quad N$-( $N^{\prime}$-Benzyloxycarbonylsulphanilyl)- $N$-methylsulphanilyl chloride $(1.48 \mathrm{~g})$ dissolved in acetonitrile $(30 \mathrm{ml})$ was added to a stirred solution of agmatine dihydrochloride $(609 \mathrm{mg})$ in water $(30 \mathrm{ml})$ and the apparent $\mathrm{pH}$ was kept at 9.5 by addition of $2 \mathrm{M}-\mathrm{NaOH}$ (in a pH-stat). When reaction ceased $(30 \mathrm{~min})$, the solution was evaporated under reduced pressure, yielding a gum which was then extracted with warm propan-2-ol. Evaporation 
of the filtered extract under reduced pressure gave the product $(93 \%)$ as an amorphous white solid. It had an ill-defined melting point and decomposed in the range $100-180^{\circ} \mathrm{C}$ depending on the rate of heating. The homogeneity of the material was demonstrated by t.l.c. on silica in chloroformmethanol-water $(11: 8: 2$, by vol.) and in pyridine-2methylbutan-2-ol-water (7:7:6, by vol.) (detected by $\mathrm{I}_{2}$ vapour) (Found: $\mathrm{C}, 48.9 ; \mathrm{H}, 5.3 ; \mathrm{N}, 12.9$. $\mathrm{C}_{26} \mathrm{H}_{33} \mathrm{ClN}_{6} \mathrm{O}_{6} \mathrm{~S}_{2}, \mathrm{H}_{2} \mathrm{O}$ requires $\mathrm{C}, 48.6 ; \mathrm{H}, 5.5$; $\mathrm{N}, 13.0 \%$ ).

$N-\alpha-\left(N^{\prime}-\right.$ Methyl $-N^{\prime}-$ sulphanilyl)sulphanilylagmatine dihydrochloride. $\quad N-\alpha-\left[N^{\prime}-\left(N^{\prime \prime}\right.\right.$-Benzyloxycarbonylsulphanilyl) - $N^{\prime}$ - methylsulphanilyl]agmatine hydrochloride was hydrogenolysed at atmospheric pressure in ethanol in the presence of $10 \%$ palladium on charcoal. The filtered solution was acidified with conc. $\mathrm{HCl}$ and evaporated to dryness under reduced pressure, giving the product $(96 \%)$ which was dried in vacuo to an amorphous solid with a poorly defined m.p. of about $106^{\circ} \mathrm{C}$ (decomp.). It resisted attempts at crystallization but was shown to be essentially homogeneous by t.l.c. on silica in methanol-chloroform-water $(11: 8: 2$, by vol.) (Found: C, 41.0; $\mathrm{H}, 5.5 ; \mathrm{S}, 12.1 . \mathrm{C}_{18} \mathrm{H}_{28} \mathrm{Cl}_{2} \mathrm{~N}_{6} \mathrm{O}_{4} \mathrm{~S}_{2}$ requires $\mathrm{C}, 41.0 ; \mathrm{H}, 5.4 ; \mathrm{S}, 12.2 \%$ ). Addition of an excess of ethanolic 1,4-dihydroxy-9,10-anthraquinone-2-sulphonic acid (rhodizonic acid) to an ethanolic solution of the dihydrochloride caused the rhodizonate salt to crystallize. This was washed with ethanol and recrystallized from 2-methoxyethanol-acetone, when it had an m.p. of about $192^{\circ} \mathrm{C}$ (decomp.), which was dependent on the rate of heating (Found: $\mathrm{C}, 49.8 ; \mathrm{H}, 4.6 ; \mathrm{S}, 11.5$. $\mathrm{C}_{32} \mathrm{H}_{35} \mathrm{~N}_{6} \mathrm{O}_{11} \mathrm{~S}_{3}$ requires $\mathrm{C}, 49.5 ; \mathrm{H}, 4.6 ; \mathrm{S}, 12.4 \%$ ).

p-( $p^{\prime}$ - Aminophenoxypropoxy)benzamidine - Seph arose and $N-\alpha-\left(N^{\prime}-\right.$ methyl- $N^{\prime}-$ sulphanilyl)sulphanilylagmatine-Sepharose conjugates. $p$-( $p^{\prime}$-Aminophenoxypropoxy)benzamidine and $N-\alpha-\left(N^{\prime}\right.$-methyl- $N^{\prime}-$ sulphanilyl)sulphanilylagmatine were coupled covalently to Sepharose by a procedure based on that of Cuatrecasas et al. (1968). In a typical preparation, Sepharose 4B $(50 \mathrm{ml}$ of settled gel) was stirred with water $(50 \mathrm{ml})$ and $\mathrm{CNBr}(5 \mathrm{~g})$ was added. The $\mathrm{pH}$ was kept at 11 by addition of $4 \mathrm{M}-\mathrm{NaOH}$ (in a pH-stat) and a little ice was added to prevent a marked rise in temperature. When alkali uptake ceased, the gel was rapidly filtered off, washed with cold $0.1 \mathrm{M}-\mathrm{NaHCO}_{3}(1000 \mathrm{ml})$ and suspended in $0.1 \mathrm{M}$ sodium acetate buffer $(50 \mathrm{ml})$ adjusted to $\mathrm{pH} 5.0$ with acetic acid. A solution of $p$-( $p^{\prime}$-aminophenoxypropoxy)benzamidine benzenesulphonate $(22.2 \mathrm{mg})$ in aq. $50 \%(\mathrm{v} / \mathrm{v})$ methanol $(5 \mathrm{ml})$ was added and the mixture was gently agitated at room temperature for $24 \mathrm{~h}$. The gel was filtered off, washed with more acetate buffer, and the content of $p$ - $\left(p^{\prime}\right.$-aminophenoxypropoxy)benzamidine in the filtrate was determined spectrophotometrically at $263 \mathrm{~nm}$. The gel was washed slowly and successively in a short column with $1 \mathrm{M}$-sodium acetate-acetic acid, pH5.0 $(1000 \mathrm{ml}), 0.2 \mathrm{M}-\mathrm{NH}_{4} \mathrm{Cl}-\mathrm{NH}_{3}, \mathrm{pH} 9.5(1000 \mathrm{ml})$, and water $(1000 \mathrm{ml})$. It was stored as a slurry in $0.02 \%$ $(w / v) \mathrm{NaN}_{3}$ at $4^{\circ} \mathrm{C}$. Coupling of the benzamidine derivative to Sepharose 2B and to Sephadex G-200 was carried out in a similar manner, but the latter shrank considerably and acquired poor flow characteristics. Coupling experiments were carried out with smaller quantities of $\mathrm{CNBr}$ and of $p$-( $p^{\prime}$-aminophenoxypropoxy)benzamidine benzenesulphonate. Normally, over $90 \%$ of the added benzamidine derivative coupled to the gel except when less than $20 \mathrm{mg}$ of $\mathrm{CNBr} / \mathrm{ml}$ of gel was used in the activation step (Table 1). Coupling of $N-\alpha-\left(N^{\prime}-\right.$ sulphanilyl)sulphanilylagmatine to Sepharose 4B was performed similarly. The acetate buffer used for the reaction between $N-\alpha$-( $N^{\prime}$-methyl- $N^{\prime}$-sulphanilyl)sulphanilylagmatine $(10 \mathrm{mg})$ and Sepharose $4 \mathrm{~B}(10 \mathrm{ml})$, which had been activated with $\mathrm{CNBr}(1 \mathrm{~g})$, usually had a pH of 4.5, but similar results were obtained at pH3.0. Unchanged agmatine derivative was determined spectrophotometrically at $270 \mathrm{~nm}$ and the results showed that $94-95 \%$ of it had become attached covalently to the gel. A test for the presence of primary aromatic amino groups, which was carried out on the products by attempted diazotization and coupling with 2-naphthol, was negative. When the reaction between activated Sepharose and the agmatine derivative was carried out in $\mathrm{NaHCO}_{3}$ buffer at $\mathrm{pH} 9.0$, however, a positive test for primary aromatic amino groups was obtained, indicating that in this case some coupling had occurred on the sulphonamido or guanidino $\mathbf{N}$ atoms.

$p$ - $\left(p^{\prime}\right.$ - Aminophenoxypropoxy)benzamidine - cellulose conjugate. Cellulose powder (Whatman CC31; $30 \mathrm{~g}$ ) was stirred with $0.5 \mathrm{M}-\mathrm{NaOH}(1200 \mathrm{ml})$ for $1 \mathrm{~h}$, washed with water until the washings were no longer alkaline, stirred with $0.5 \mathrm{M}-\mathrm{HCl}$ for $1 \mathrm{~h}$ and rewashed with water. Fines were removed and the remaining cellulose (66ml packed vol.) was activated with $\mathrm{CNBr}(2.5 \mathrm{~g})$, washed and allowed to react with the benzamidine benzenesulphonate $(22.2 \mathrm{mg})$ in $0.1 \mathrm{M}$ sodium acetate buffer, pH5.0. The product was washed as described for the Sepharose derivatives; $96 \%$ of the benzamidine derivative had become attached covalently to the cellulose.

Soya-bean trypsin inhibitor-Sepharose conjugate. Sepharose 4B ( $39 \mathrm{ml}$ of settled gel) was activated with $\mathrm{CNBr}(4.0 \mathrm{~g})$, washed with cold $0.1 \mathrm{M}-\mathrm{NaHCO}_{3}$ $(800 \mathrm{ml})$ and suspended in $0.1 \mathrm{M}-\mathrm{NaHCO}_{3}$ buffer, pH9.0. A solution of soya-bean trypsin inhibitor $(176 \mathrm{mg})$ in water $(4 \mathrm{ml})$ was added and the mixture was gently stirred overnight at $4^{\circ} \mathrm{C}$. After the product was washed, spectrophotometric assay of the washings at $280 \mathrm{~nm}$ showed that the gel contained $2.9 \mathrm{mg}$ of trypsin inhibitor $/ \mathrm{ml}$ (65\% coupling efficiency). 


\section{Methods}

Solutions of trypsin were kept at $0-4^{\circ} \mathrm{C}$; stock enzyme solutions for kinetic measurements were made up in $1 \mathrm{~mm}-\mathrm{HCl}$ containing $20 \mathrm{~mm}-\mathrm{CaCl}_{2}$. Measurements of $\mathrm{pH}$ were made at room temperature. Concentrations of buffer constituents are given as final concentrations.

Column chromatography. Columns were maintained at $4^{\circ} \mathrm{C}$. Eluent was delivered by means of a peristaltic pump and eluent gradients were linear. The column effluent was monitored at $280 \mathrm{~nm}$ with a Uvicord u.v. analyser (LKB-Produkter AB, Stockholm, Sweden) and checked manually in selected cases on a spectrophotometer. The effluent was divided into timed fractions and delivered into test tubes maintained at $4^{\circ} \mathrm{C}$ in a water bath. Fractions that were to be freeze-dried were concentrated where necessary by ultrafiltration at $0^{\circ} \mathrm{C}$ through a Diaflo UM-10 membrane (Amicon Corp., Lexington, Mass., U.S.A.) and desalted by gel-filtration chromatography in $1 \mathrm{~mm}-\mathrm{HCl}$ by using a short column of Sephadex G-25.

Measurement of protein concentrations. Trypsin concentrations were obtained from measurements of the extinction at $280 \mathrm{~nm}$; values of $E_{1 \mathrm{~cm}}^{1 \%}$ and molecular weight were taken as 15.6 (Baines et al., 1964) and 23800 (Cunningham, 1954) respectively.

Determination of the operational molarity of trypsin solutions. In early experiments, the total content of active ( $\alpha$ - and $\beta$-)trypsin in solutions was determined by titration with $p^{\prime}$-nitrophenyl $p$ guanidinobenzoate at pH8.3 (Chase \& Shaw, 1967). In addition, titrations were performed at pH4.0 (Hruska et al., 1969) in attempts to determine the relative proportions of $\alpha$ - and $\beta$-trypsin. In most cases, however, trypsin solutions were titrated spectrofluorimetrically with 4-methylumbelliferyl $p$-guanidinobenzoate at $\mathrm{pH} 8.3$ and $25^{\circ} \mathrm{C}$ (Jameson et al., 1973). As previously reported, $\beta$-trypsin was acylated by the latter reagent in a few seconds, but the reaction with $\alpha$-trypsin required over $10 \mathrm{~min}$ and this difference was exploited for the determination of the amounts of each form of enzyme present. Although the acylation of $\alpha$-trypsin by 4-methylumbelliferyl $p$-guanidinobenzoate obeyed pseudo-first-order kinetics fairly well under the conditions used, it was preferred to calculate the amount of $\alpha$-trypsin present by a curve-fitting procedure which required no assumptions about the order of the reaction. Fluorescence-intensity readings were taken at intervals varying from a few seconds to several minutes depending on the rate of change of fluorescence intensity. After the first few seconds, changes in fluorescence intensity (corrected for the non-enzymic hydrolysis of 4-methylumbelliferyl p-guanidinobenzoate) were due only to the acylation of $\alpha$-trypsin. A computed curve was fitted to these readings by the method involving orthogonal polynomials by using the program described by Elmore et al. (1963) and since rewritten in FORTRAN for the ICL 1907 computer. The value of the fluorescence intensity at zero time obtained by back-extrapolation of the computed curve was taken as a measure of the content of $\beta$-trypsin in the sample, and the content of $\alpha$-trypsin could then be obtained from the difference in fluorescence intensity at zero time and when acylation was complete.

Determination of the operational molarity of $\alpha$-chymotrypsin solutions. Solutions of $\alpha$-chymotrypsin were titrated with 4-methylumbelliferyl $p$-(NNN-trimethylammonium) cinnamate as described by Jameson et al. (1973).

Measurement of the trypsin-binding capacity of affinity adsorbents. A known excess (2-4-fold) of bovine trypsin was applied to a small column (about $0.9 \mathrm{~cm} \times 3 \mathrm{~cm}$ ) in a $\mathrm{pH} 8.0$ buffer, usually of $0.05 \mathrm{M}$-triethanolamine hydrochloride-triethanolamine containing $10 \mathrm{~mm}-\mathrm{CaCl}_{2}$. The column was washed with this buffer until elution of protein had essentially ceased; the concentration of trypsin in the pooled effluent was determined by measuring $E_{280}$ and by spectrofluorimetric titration with 4-methylumbelliferyl p-guanidinobenzoate. The amount of trypsin bound by the affinity adsorbent could then be calculated. The bound enzyme was eluted with a solution of $0.5 \mathrm{M}-n$-butylamine hydrochloride in the triethanolamine buffer or alternatively with a solution of $0.1 \mathrm{M}$-citric acid containing $1 \mathrm{M}$ $\mathrm{NaCl}$. The trypsin content of the pooled effluent was determined as above giving the trypsin-binding capacity of the column directly. Four values of the trypsin-binding capacity were thus obtained. Although serious discrepancies between the four values were observed only when a very large excess of trypsin was used, it was considered that the spectrophotometric determination of the protein content of the effluent obtained in the second step was most reliable because (a) the spectrophotometric method applied to the first effluent would overestimate the amount of unbound trypsin if inert protein were present and $(b)$ titration of either fraction with 4-methylumbelliferyl $p$ guanidinobenzoate would underestimate trypsin if any autolysis occurred during the binding and elution procedures.

Identification of $N$-terminal amino acids. Dansylation of trypsin samples was carried out in $0.1 \mathrm{M}-\mathrm{NaHCO}_{3}$ and in $0.25 \mathrm{M}-\mathrm{NaHCO}_{3}$ containing 4M-urea as described by Gray (1967) and Hartley (1970). The solvent in both cases contained $50 \%(\mathrm{v} / \mathrm{v})$ acetone. In the latter case, the solution of dansylated protein was desalted by gel filtration before hydrolysis. Dansyl-amino acids in the acid hydrolysates were separated by t.l.c. on polyamide layers as described by Hartley (1970). 
Steady-state kinetic measurements. These were carried out with a recording pH-stat by using $S$-(2aminoethyl)- $N$-benzoyl-L-cysteine methyl ester hydrochloride and $\alpha$ - $N$-benzoyl-L-arginine ethyl ester hydrochloride as substrates. Detailed descriptions of the experimental and computational methods have been given elsewhere (Elmore et al., 1963; Baines et al., 1964).

\section{Results}

\section{Affinity adsorbents}

The insoluble support chosen for most of the affinity adsorbents was agarose (Cuatrecasas $e t$ al., 1968). Cellulose has also been found to be satisfactory, an observation independently reported by Lowe \& Dean (1971) and Uren (1971). The structures of synthetic inhibitors were devised so that the enzyme-specific moieties were held well away from the supporting matrix (Cuatrecasas, 1970). $p$ - $\left(p^{\prime}-\right.$ Aminophenoxypropoxy)benzamidine was selected as a compound structurally related to trypsin inhibitors with $K_{t}$ values in the range 2-8 $\mu \mathrm{M}$ (Baker \& Erickson, 1968). The spacing group comprises an aromatic ring and a flexible ether-linked aliphatic chain. The successful use of affinity adsorbents based on $p$ - $\left(p^{\prime}\right.$-aminophenoxypropoxy)benzamidine must be due to these structural features and/or their low $K_{t}$ values. Table 1 lists the activation conditions, coupling yields, content of inhibitor and trypsinbinding capacity for affinity adsorbents containing this inhibitor. $N$ - $\alpha$-( $N^{\prime}$-Methyl- $N^{\prime}$-sulphanilyl)sulphanilylagmatine was chosen as an analogue of the known trypsin inhibitor, $\alpha-N$-toluene-p-sulphonylagmatine (Rule \& Lorand, 1964) for which the $K_{t}$ value is of the order of $1 \mathrm{~mm}$. The two sulphanilyl groups provide a linear rigid arm by which the agmatine moiety is linked to the matrix. Soya-bean trypsin inhibitor was chosen as a representative of the natural trypsin inhibitors and the addition of a spacer was considered unnecessary.

Chromatographic behaviour of soya-bean trypsin inhibitor-Sepharose conjugate

Bovine serum albumin was only slightly retarded when applied to a column of soya-bean trypsin inhibitor-Sepharose conjugate in $50 \mathrm{~mm}$-Tris- $\mathrm{HCl}$ buffer containing $10 \mathrm{~mm}-\mathrm{CaCl}_{2}, \mathrm{pH} 7.8$, but bovine trypsin was bound to the adsorbent in this buffer and was subsequently eluted with $1 \mathrm{M}-n$-butylamine hydrochloride, a competitive inhibitor of trypsin $\left(K_{\iota}=1.7 \mathrm{~mm}\right.$; Inagami, 1964), at $\mathrm{pH}$ 3.0. A saturation experiment showed that the trypsin-binding capacity of the adsorbent, as measured by titration of the effluent with $p^{\prime}$-nitrophenyl $p$-guanidinobenzoate, was $2.4 \mathrm{mg}$ of trypsin $/ \mathrm{ml}$ of gel. Bovine $\alpha$-chymotrypsin bound to the adsorbent in $\mathrm{pH} 8.2$ borate buffer (10mm- $\mathrm{Na}_{2} \mathrm{~B}_{4} \mathrm{O}_{7}, 2 \mathrm{~mm}-\mathrm{CaCl}_{2}, 50 \mathrm{~mm}-\mathrm{NaCl}$, adjusted with $\mathrm{HCl}$ ) and also in $\mathrm{pH} 6.010 \mathrm{~mm}$-sodium cacodylate- $\mathrm{HCl}$ buffer containing $2 \mathrm{~mm}-\mathrm{CaCl}_{2}$. In both cases, the $\alpha$-chymotrypsin was eluted with $0.5 \mathrm{M}$ - $n$-butylamine hydrochloride in $0.1 \mathrm{M}$-acetic acid. These results resemble those reported by Feinstein (1970b). When chromatography was carried out in $0.1 \mathrm{M}$-sodium formate-formic acid buffer, pH3.5, some selectivity for trypsin emerged; $\alpha$-chymotrypsin was virtually unretarded, whereas most of the trypsin activity was retarded and appeared as a very broad peak immediately after a peak of inert protein. No evidence of the resolution of $\alpha$ and $\beta$-trypsin was obtained by gradient elution of trypsin bound to the affinity adsorbent in $\mathrm{pH} 7.8$ $50 \mathrm{~mm}$-Tris buffer containing $10 \mathrm{mM}-\mathrm{CaCl}_{2}$. In these experiments, $\mathrm{pH}$ gradients (obtained by mixing the above Tris buffer with an equal volume of $0.05 \mathrm{M}$ sodium citrate buffer, $\mathrm{pH} 3.5$ ), concentration gradients of $n$-butylamine hydrochloride (to $1 \mathrm{M}$ at $\mathrm{pH} 7.8$ )

Table 1. Characteristics of the affinity adsorbents derived from $p$-( $p^{\prime}$-aminophenoxypropoxy)benzamidine: relative amounts of $\mathrm{CNBr}$ used in activation of supports, efficiency of the inhibitor coupling reactions, inhibitor contents of the adsorbents and their actual trypsin-binding capacities

For details see the text. Available trypsin-binding capacity is calculated as a percentage of a theoretical trypsin-binding capacity equivalent to the inhibitor content of the adsorbent.

\begin{tabular}{|c|c|c|c|c|c|}
\hline Support & $\begin{array}{c}\text { CNBr used } \\
\text { in activation } \\
(\mathrm{mg} / \mathrm{ml} \text { of support) }\end{array}$ & $\begin{array}{c}\text { Yield of } \\
\text { inhibitor-coupling } \\
\text { reaction } \\
(\% \text { coupled })\end{array}$ & $\begin{array}{l}\text { Inhibitor content } \\
\text { adsorbents } \\
(\mu \mathrm{mol} / \mathrm{ml})\end{array}$ & $\begin{array}{l}\text { Trypsin-binding } \\
\text { capacity of } \\
\text { adsorbents } \\
\text { (mg of enzyme/ } \\
\text { ml of adsorbent) }\end{array}$ & $\begin{array}{c}\text { Available } \\
\text { trypsin-binding } \\
\text { capacity of } \\
\text { adsorbents } \\
(\%)\end{array}$ \\
\hline epharose 4B & 100 & 94 & 0.940 & 3.46 & 15.4 \\
\hline Sepharose 4B & 100 & $44^{*}$ & 0.435 & 1.26 & 12.2 \\
\hline Sepharose 4B & 20 & 91 & 0.182 & 0.52 & 12.0 \\
\hline Sepharose 2B & 5 & 65 & 0.647 & $1.4,1.1$ & $8.9,7.1$ \\
\hline Cellulose powder & 38 & 96 & 0.717 & 0.49 & 2.8 \\
\hline
\end{tabular}

* The reason for this unexpectedly low value is not known.

Vol. 141 
and a combined gradient were all used. These results prompted us to investigate the possible use of insolubilized synthetic trypsin inhibitors, although other natural trypsin inhibitors have been shown to provide useful affinity adsorbents for trypsin (Robinson et al., 1971; Feinstein, 1970a,b).

\section{Chromatographic behaviour of $N-\alpha-\left(N^{\prime}-\right.$ methyl- $N^{\prime}-$ sulphanilyl)sulphanilylagmatine-Sepharose conjugate}

This agmatine derivative exhibited more selectivity for trypsin than did the soya-bean trypsin inhibitor-Sepharose conjugate. Bovine $\alpha$-chymotrypsin $(5 \mathrm{mg})$ applied to a column $(0.6 \mathrm{~cm} \times 7 \mathrm{~cm})$ of $N-\alpha-\left(N^{\prime}\right.$-methyl- $N^{\prime}$-sulphanilyl)sulphanilylagmatine-Sepharose conjugate and eluted with a pH8.0 Tris buffer $\left(10 \mathrm{~mm}-\mathrm{Tris}-\mathrm{HCl}\right.$ containing $2 \mathrm{~mm}-\mathrm{CaCl}_{2}$, $I=0.022 \mathrm{~mol} / \mathrm{l})$ was only very slightly retarded, but bovine trypsin $(5 \mathrm{mg})$, chromatographed under the same conditions, yielded two peaks of protein. The first was largely inert protein and contained only $0.4 \mathrm{mg}$ of active trypsin as determined by titration with $p^{\prime}$-nitrophenyl $p$-guanidinobenzoate. The second peak was very broad, with a long training edge, and contained $1.2 \mathrm{mg}$ of trypsin. Elution with $0.1 \mathrm{M}$-acetic acid then yielded a third peak containing $0.6 \mathrm{mg}$ of trypsin. Titration with $p^{\prime}$-nitrophenyl $p$-guanidinobenzoate at $\mathrm{pH} 4.0$ showed that the last two peaks contained about the same proportions of $\alpha$ - and $\beta$-trypsins. Similar results were obtained when the trypsin was applied to the column in a pH6.0 buffer (10mM-sodium cacodylate- $\mathrm{HCl}$ containing $2 \mathrm{~mm}$ $\left.\mathrm{CaCl}_{2}, I=0.022 \mathrm{~mol} / \mathrm{l}\right)$ and again finally eluted with $0.1 \mathrm{M}$-acetic acid. Replacement of the acetic acid elution step with a $\mathrm{NaCl}$ concentration gradient yielded all the enzyme remaining bound in a single peak $(1.2 \mathrm{mg}$ of trypsin) at $I=0.18 \mathrm{~mol} / 1$. Ionic strength also markedly influenced the binding of trypsin to the affinity column in three buffers at pH 8.0. These buffers (10mm-Tris, $10 \mathrm{~mm}-\mathrm{Na}_{2} \mathrm{~B}_{4} \mathrm{O}_{7}$ and $10 \mathrm{~mm}$-sodium barbiturate, adjusted to $\mathrm{pH} 8.0$ with $\mathrm{HCl}, \mathrm{H}_{3} \mathrm{BO}_{3}$ and $\mathrm{HCl}$ respectively and all containing $2 \mathrm{~mm}-\mathrm{CaCl}_{2}$ ) were adjusted to the required ionic strength with $\mathrm{NaCl}$. For $I \geqslant 0.07 \mathrm{~mol} / 1$, most of the trypsin was eluted in a single unretarded peak, whereas at $I=0.02 \mathrm{~mol} / \mathrm{l}$, two peaks were obtained and some trypsin remained bound as described above.

$N$ - $\alpha$ - $\left(N^{\prime}\right.$ - Methyl - $N^{\prime}$ - sulphanilyl)sulphanilylag matine-Sepharose conjugate clearly functions as a specific affinity adsorbent for bovine trypsin, but only at low ionic strengths. This undesirable property may be due to the high $K_{l}$ values of agmatine derivatives or to the rigid linear structure of the inhibitor, or both. The elution of two main peaks, which both contain $\alpha$ - and $\beta$-trypsin, after the enzyme has been applied to the column in pH6.0 or 8.0 buffers of $I=0.02 \mathrm{~mol} / 1$ and eluted at low $\mathrm{pH}$ or high ionic strength is an additional unsatisfactory feature. This behaviour may stem from the linkage of the agmatine derivative to Sepharose by more than one type of covalent bond, effectively forming multiple types of insolubilized inhibitor. Supporting this theory, it is known that $N$-substituted imidocarbonates, isourea derivatives and $N$-substituted carbamates are all formed when amines are coupled to $\mathrm{CNBr}$ activated polysaccharides (Axén \& Ernback, 1971). The additional possible complication that coupling might have involved the guanidino atoms is considered unlikely, since chemical tests showed that the affinity adsorbent did not contain free amino groups.

\section{Chromatographic behaviour of $p$-( $p^{\prime}$-aminophenoxy- propoxy)benzamidine-Sepharose conjugate}

When crude trypsin was applied to a column of this affinity adsorbent in 50mm-triethanolamine hydrochloride-triethanolamine buffer, $\mathrm{pH} 8.0$, containing $10 \mathrm{~mm}-\mathrm{CaCl}_{2}$, the enzyme was bound and a peak of inactive protein was soon eluted (Fig. 1a). Subsequent elution with $0.2 \mathrm{M}-\mathrm{KCl}$ containing $1 \mathrm{~mm}-\mathrm{HCl}$ yielded only an insignificant quantity of protein. Development with $10 \mathrm{~mm}-\mathrm{HCl}$ containing $0.5 \mathrm{M}-n$-butylamine hydrochloride eluted the bound trypsin in a single peak, which contained $86 \%$ of active enzyme and represented $80 \%$ of the original enzyme applied to the column. Subsequent experiments showed $n$-butylamine hydrochloride $(\geqslant 0.25 \mathrm{M})$ to be an effective eluent in the $\mathrm{pH}$ range 2.0-8.0. When the inhibitor was applied in a concentration gradient in a pH8.0 50mm-triethanolamine hydrochloride-triethanolamine buffer containing $10 \mathrm{~mm}$ $\mathrm{CaCl}_{2}$, the bound trypsin was eluted in a single broad peak when the concentration of $n$-butylamine hydrochloride was approx. $0.13 \mathrm{M}$. Various final eluents of $\mathrm{pH} 2.0-2.5$ eluted the bound trypsin as effectively as solutions of $n$-butylamine hydrochloride. These included: $0.1 \mathrm{M}$-citric acid- $1 \mathrm{M}-\mathrm{NaCl}$, $\mathrm{pH} 2.0 ; 0.1 \mathrm{M}$-formic acid, $\mathrm{pH} 2.4 ; 0.2 \mathrm{M}$-formic acidsodium formate buffer containing $0.5 \mathrm{M}-\mathrm{NaCl}$, $\mathrm{pH} 2.5$. Less predictably, the bound trypsin was also eluted by water, although continuously rather than as a discrete peak. The elution by water of proteins bound to affinity adsorbents is uncommon but not unknown (Vahlquist et al., 1971; Blumberg et al., 1970).

The specificity of the affinity column was demonstrated by its failure to bind $\alpha$-chymotrypsin significantly in a pH6.0 buffer (50mm-sodium succinate- $\mathrm{HCl}$ containing $10 \mathrm{~mm}-\mathrm{CaCl}_{2}$ ) (Fig. 1 b), or in a pH 8.0 buffer (50 mM-triethanolamine hydrochloride-triethanolamine containing $10 \mathrm{~mm}-\mathrm{CaCl}_{2}$ ). The content of active $\alpha$-chymotrypsin in the first peak was $94 \%$ of the total enzyme applied.

The trypsin-binding capacity of the affinity column was usually $1-3 \mathrm{mg} / \mathrm{ml}$ of gel (Table 1 ), but only a small proportion $(7-16 \%)$ of the insolubilized 

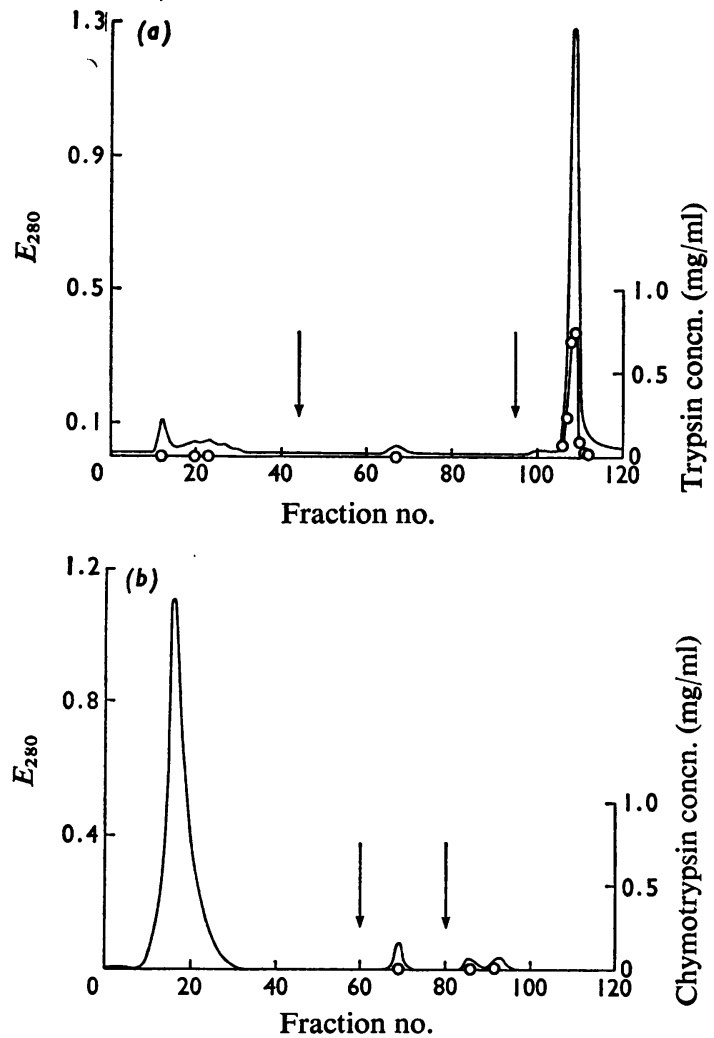

Fig. 1. Chromatography of bovine trypsin and $\alpha$-chymotrypsin on $p$-( $p^{\prime}$-aminophenoxypropoxy)benzamidine-Sepharose conjugate

(a) Trypsin $(20 \mathrm{mg})$ was applied to a column $(1.5 \mathrm{~cm} \times 25 \mathrm{~cm})$ of affinity adsorbent in $50 \mathrm{~mm}$-triethanolamine hydrochloride-triethanolamine buffer containing $10 \mathrm{mM}-\mathrm{CaCl}_{2}$, pH 8.0. The eluent was changed to $1 \mathrm{~mm}-\mathrm{HCl}$ containing $0.2 \mathrm{M}-\mathrm{KCl}$ at the first arrow and then to $10 \mathrm{mM}-\mathrm{HCl}$ containing $0.5 \mathrm{M}-n$-butylamine hydrochloride at the second arrow. -,$E_{280} ; O$, active trypsin concentration as measured by titration with 4-methylumbelliferyl $p$ guanidinobenzoate. Flow rate, $24 \mathrm{ml} / \mathrm{h}$; fraction size, $6.0 \mathrm{ml}$. (b) Chymotrypsin (20 mg) was applied to the column in $50 \mathrm{~mm}$-sodium succinate- $\mathrm{HCl}$ buffer containing $10 \mathrm{~mm}-\mathrm{CaCl}_{2}, \mathrm{pH} 6.0$. The eluent was changed to $50 \mathrm{~mm}$-sodium succinate- $\mathrm{HCl}$ containing $0.5 \mathrm{M}-\mathrm{NaCl}$, pH6.0, at the first arrow and then to $0.2 \mathrm{M}$-formic acidsodium formate containing $0.5 \mathrm{M}-\mathrm{NaCl}, \mathrm{pH} 2.5$, at the second arrow. Flow rate, $20 \mathrm{ml} / \mathrm{h}$; fraction size, $4.9 \mathrm{ml}$. Symbols are as in $(a)$.

inhibitor was actually available for enzyme binding. This phenomenon appears to be unrelated to the relative amount of $\mathrm{CNBr}$ used in the activation process and is therefore unlikely to be due to a substantial decrease in the gel pore size, which could arise if cross-linking of the gel occurred. Chromatography on $p$-( $p^{\prime}$-aminophenoxypropoxy)benzamidine-Sepharose conjugate is a useful means of ridding trypsin of other proteins, including $\alpha$-chymotrypsin, and it could be used to free $\alpha$-chymotrypsin of contaminating trypsin.

\section{Chromatographic behaviour of $p$ - $\left(p^{\prime}\right.$-aminophenoxy- propoxy)benzamidine-cellulose conjugate}

Trypsin bound strongly to this adsorbent in buffers composed either of $50 \mathrm{mM}$-triethanolamine hydrochloride-triethanolamine, $\mathrm{pH} 8.0$, or of $0.2 \mathrm{M}$ $\mathrm{NH}_{4} \mathrm{HCO}_{3}-\mathrm{NH}_{3}, \mathrm{pH} 8.4$, both buffers containing $10 \mathrm{~mm}-\mathrm{CaCl}_{2}$. The binding of the enzyme was unaffected by the inclusion of $0.5 \mathrm{M}-\mathrm{NaCl}$ in the former buffer. Complete elution of the bound enzyme could be effected by solutions of low $\mathrm{pH}$ including: $0.1 \mathrm{M}$ citric acid-1 M-NaCl, pH 2.0; $0.1 \mathrm{M}$-citric acid-0.1 M$\mathrm{NaCl}, \mathrm{pH} 2.1 ; 20 \mathrm{~mm}-\mathrm{HCl} ; 50 \mathrm{~mm}$-citric acid-50mm$\mathrm{NaCl}, \mathrm{pH} 2.4$. In contrast, although dilute formic acid easily eluted trypsin from $p$ - $\left(p^{\prime}\right.$-aminophenoxypropoxy)benzamidine-Sepharose conjugate, $0.3 \mathrm{M}$ formic acid was only partially effective when the enzyme was bound to the corresponding inhibitorcellulose conjugate.

Chromatography of bovine trypsin on $p$ - $\left(p^{\prime}-\right.$ aminophenoxypropoxy)benzamidine-cellulose conjugate under conditions resembling those described in Fig. 1 yielded a very similar elution profile, and the main difference lies in the binding capacities of the two affinity adsorbents. $p$-( $p^{\prime}$-Aminophenoxypropoxy)benzamidine-cellulose conjugate contained at least as much inhibitor as did the corresponding inhibitor-Sepharose conjugate, but the proportion of coupled inhibitor available for binding trypsin was much lower in the former case (Table 1). It is possible that binding of enzyme may be subject to serious steric hindrance as a result of the impermeable crystalline structure of cellulose.

\section{Isolation of $\beta$-trypsin by using $p$ - $\left(p^{\prime}\right.$-aminophenoxy-} propoxy)benzamidine-cellulose conjugate

Experiments with a $\mathrm{pH}$ gradient showed that it was possible to elute pure $\beta$-trypsin specifically after crude trypsin had been bound by the affinity adsorbent. The effects of eluent composition are important and are discussed below. From these early observations, a stepwise elution scheme was developed which offers a very convenient and rapid method for isolating bovine $\beta$-trypsin (Fig. 2). Crude bovine trypsin $(20 \mathrm{mg})$ was applied to a column of $p-\left(p^{\prime}-\right.$ aminophenoxypropoxy)benzamidine-cellulose conjugate in $50 \mathrm{~mm}$-triethanolamine hydrochloridetriethanolamine buffer containing $10 \mathrm{mM}-\mathrm{CaCl}_{2}$ at pH 8.0. Elution with this buffer yielded a peak of inert protein. An abrupt change of eluent to $50 \mathrm{~mm}$ sodium acetate-acetic acid, $\mathrm{pH} 5.0$, gave a peak of 
$\beta$-trypsin (5.1-5.3 mg). Assay with 4-methylumbelliferyl $p$-guanidinobenzoate showed that $\alpha$-trypsin was absent and that the $\beta$-trypsin was $90-94 \%$ active. Its identity with $\beta$-trypsin, isolated by the method of Schroeder \& Shaw (1968), was confirmed by measurement of the $K_{m}$ and $k_{\text {cat }}$. values by using $S$-(2-aminoethyl)- $N$-benzoyl-L-cysteine methyl ester as the substrate (Table 2) and by demonstrating the presence of only one $N$-terminal residue, isoleucine. After $\beta$-trypsin had been removed from the column, a further quantity of enzyme (5.2-5.3 mg), which was shown to contain $18 \% \alpha$-trypsin by titration with 4-methylumbelliferyl p-guanidinobenzoate, was eluted with a solution of $50 \mathrm{~mm}$-citric acid containing $50 \mathrm{~mm}-\mathrm{NaCl}, \mathrm{pH} 2.3$.

Isolation of $\alpha$ - and $\beta$-trypsin by using $p$ - $\left(p^{\prime}\right.$-aminophenoxypropoxy)benzamidine-Sepharose conjugate

The behaviour of trypsin on this affinity adsorbent depends strongly on the composition of the eluent, and this is discussed below. A successful separation of $\alpha$ - and $\beta$-trypsin is shown in Fig. 3. In this experiment, crude bovine trypsin $(50 \mathrm{mg})$ was applied to a column $(1.5 \mathrm{~cm} \times 25 \mathrm{~cm})$ of $p$ - $\left(p^{\prime}\right.$-aminophenoxypropoxy)benzamidine-Sepharose 4B conjugate in $50 \mathrm{~mm}$-sodium acetate-acetic acid buffer, pH4.0, and eluted at $55 \mathrm{ml} / \mathrm{h}$. The three incompletely resolved peaks successively eluted were shown by titration with 4-methylumbelliferyl p-guanidinobenzoate to consist of inert protein, $\alpha$-trypsin and $\beta$-trypsin respectively. The fraction containing $\beta$-trypsin was very dilute and it was necessary to concentrate the solution by ultrafiltration at $0^{\circ} \mathrm{C}$ and to desalt it on Sephadex G-25 before it was freeze-dried. The yields of $\alpha$ - and $\beta$-trypsin isolated were 3.8 and $12.4 \mathrm{mg}$ respectively and the enzymes were obtained in states of purity $(\geqslant 97 \%)$ at least as good as those attainable by chromatography on sulphoethyl-Sephadex (Schroeder \& Shaw, 1968). The identity of our preparations with those obtained by Schroeder \& Shaw (1968) was again confirmed by measurement of $K_{m}$ and $k_{\text {cat. }}$ with $S$-(2-aminoethyl)- $N$-benzoyl-L-cysteine methyl ester as substrate (Table 2). A firmly bound fraction of enzyme $(3.4 \mathrm{mg})$ was eluted with $0.1 \mathrm{M}$-citric acid containing $1 \mathrm{M}-\mathrm{NaCl}$ and contained $20 \% \alpha$-trypsin.

This procedure conveniently gives both $\alpha$ - and $\beta$ trypsin, but the latter is obtained as a very dilute solution; the method was therefore used only when $\alpha$-trypsin was specifically sought. Since this form of the enzyme lost activity significantly in a few hours at $\mathrm{pH} 4.0$ and $0^{\circ} \mathrm{C}$, a high flow rate and rapid processing of the effluent were necessary to obtain good yields. $\beta$-Trypsin was much more stable in solution. The same relative stabilities were observed with freeze-dried samples of $\alpha$ - and $\beta$-trypsin prepared by the method of Schroeder \& Shaw (1968) and stored at $-20^{\circ} \mathrm{C}$ for approx. 2 years. Titration with 4 -methylumbelliferyl $p$-guanidinobenzoate showed that $\beta$ trypsin had retained much of its activity, but $\alpha$ trypsin was virtually inactive.

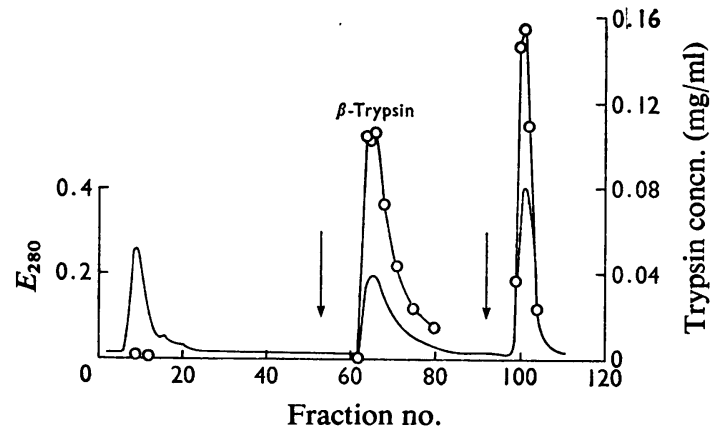

Fig. 2. Isolation of bovine $\beta$-trypsin by affinity chromatography of crude trypsin on $p$-( $p^{\prime}$-aminophenoxypropoxy)benzamidine-cellulose conjugate

Crude trypsin $(20 \mathrm{mg})$ was applied to a column $(2.2 \mathrm{~cm} \times$ $14.3 \mathrm{~cm}$ ) of affinity adsorbent in $50 \mathrm{~mm}$-triethanolamine hydrochloride-triethanolamine buffer containing $10 \mathrm{~mm}$ $\mathrm{CaCl}_{2}, \mathrm{pH}$ 8.0. The eluent was changed to $50 \mathrm{~mm}$-sodium acetate-acetic acid, pH 5.0, at the first arrow and to $50 \mathrm{~mm}$ citric acid containing $50 \mathrm{~mm}-\mathrm{NaCl}, \mathrm{pH} 2.3$, at the second arrow. - $-E_{280} ; 0$, active trypsin concentration as measured by titration with 4-methylumbelliferyl $p$ guanidinobenzoate. Flow rate, $19 \mathrm{ml} / \mathrm{h}$; fraction size, $5.0 \mathrm{ml}$.

Table 2. $k_{\mathrm{cat}}$ and $K_{m}$ values for the hydrolysis of $S$ - $(\beta$-aminoethyl $)-N$-benzoyl-L-cysteine methyl ester at pH 8.0 and $25.0^{\circ} \mathrm{C}$ by $\alpha$-and $\beta$-trypsin isolated both by affinity chromatography and by ion-exchange chromatography on sulphoethyl-Sephadex

Values are means \pm s.D.

\begin{tabular}{rlrrr} 
Enzyme & \multicolumn{1}{c}{ Source } & $k_{\text {cat. }}\left(\mathrm{s}^{-1}\right)$ & $1 \times 10^{4} K_{m}$ (M) & No. of runs \\
$\alpha$-Trypsin & Affinity chromatography & $10.3 \pm 0.2$ & $0.77 \pm 0.03$ & 9 \\
& Ion-exchange chromatography* & $8.8 \pm 0.1$ & $1.10 \pm 0.04$ & 10 \\
$\beta$-Trypsin & Affinity chromatography & $32.8 \pm 0.5$ & $1.07 \pm 0.05$ & 9 \\
& Ion-exchange chromatography* & $35.0 \pm 0.6$ & $1.04 \pm 0.04$ & 12
\end{tabular}

* Values taken from Roberts \& Elmore (1974). 
Effect of elution conditions on the resolution of $\alpha$ - and $\beta$-trypsinonp-( $p^{\prime}$-aminophenoxypropoxy)benzamidinecellulose and-Sepharose conjugates

The development of the foregoing successful methods for the isolation of $\alpha$ - and $\beta$-trypsin was the culmination of an extensive study of different elution conditions which revealed that the resolution of the mixture of enzymes depended on factors such as $\mathrm{pH}$, ionic strength, nature of the buffer species and flow rate. The choice of support for the insolubilized inhibitor is another variable. The results of some of our experiments are summarized in Tables 3 and 4.

\section{Discussion}

The results of some of our experiments could not have been predicted in advance and cannot be fully explained in retrospect. For example, the order of elution of $\alpha$ - and $\beta$-trypsin from the $p$-( $p^{\prime}$-phenoxypropoxy) benzamidine-cellulose complex depends on the nature of the eluting buffer (Fig. 2, Table 3). Some of the experiments summarized here indicate that successful separation of closely related proteins by affinity chromatography is largely serendipitous in the present state of our knowledge. This situation might be modified in the light of the critical appraisal (O'Carra et al., 1974) of the current state of the art of affinity chromatography. It is probable that the behaviour of $\alpha$ - and $\beta$-trypsin on the various inhibitor conjugates is not due to bioaffinity alone but involves compound affinity as defined by O'Carra et al. (1974). The predominantly hydro-

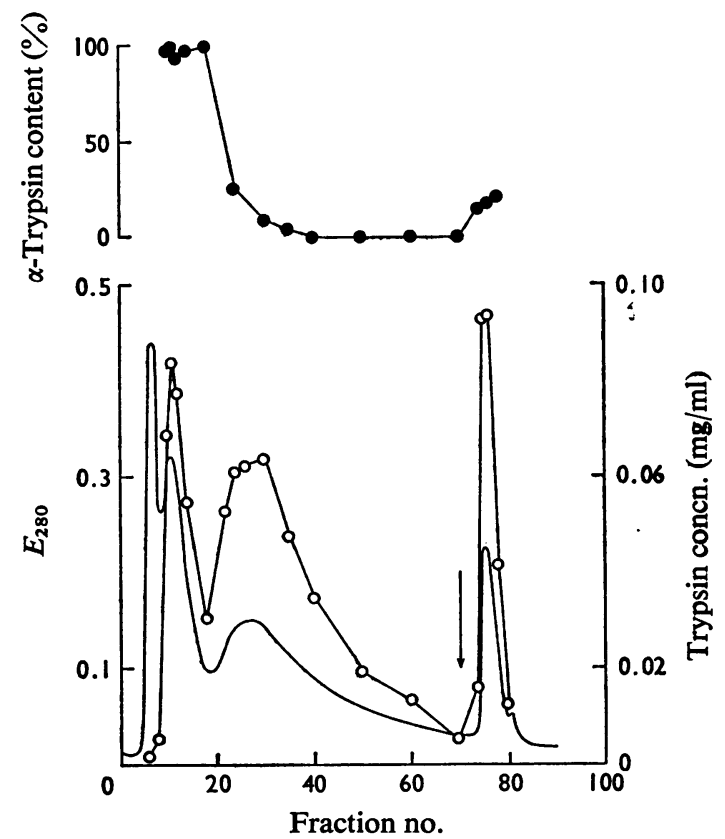

Fig. 3. Separation of bovine $\alpha$ - and $\beta$-trypsin by affinity chromatography on $p$-( $p^{\prime}$-aminophenoxypropoxy)benzamidine-Sepharose conjugate

Crude trypsin $(50 \mathrm{mg})$ was applied to a column $(1.5 \mathrm{~cm} \times$ $25 \mathrm{~cm}$ ) of affinity adsorbent in $50 \mathrm{~mm}$-sodium acetateacetic acid buffer, pH4.0. The eluent was changed to $0.1 \mathrm{M}$-citric acid containing $1 \mathrm{M}-\mathrm{NaCl}, \mathrm{pH} 2.0$, at the arrow. - $E_{280} ; O$, active trypsin concentration as measured by titration with 4-methylumbelliferyl $p$ guanidinobenzoate; $\boldsymbol{\theta}$, percentage of $\alpha$-trypsin in the total trypsin present. Flow rate, $55 \mathrm{ml} / \mathrm{h}$; fraction size, $9.2 \mathrm{ml}$.

Table 3. Effect of elution conditions on the resolution of $\alpha$ - and $\beta$-trypsin on $p$-( $p^{\prime}$-aminophenoxypropoxy)benzamidinecellulose conjugate

Loading buffer

$50 \mathrm{~mm}$-Triethanolamine $50 \mathrm{~mm}$-Sodium acetate-acetic acid, $\mathrm{pH} 4.0$ hydrochloride-triethanolamine containing $10 \mathrm{~mm}$ -

$\mathrm{CaCl}_{2}, \mathrm{pH} 8.0$

$0.2 \mathrm{M}$-Ammonium formate$\mathrm{NH}_{3}, \mathrm{pH} 8.4$

Vol. 141
50 mM-Sodium cacodylate- $\mathrm{HCl}, \mathrm{pH} 5.8$

$50 \mathrm{~mm}$-Ammonium acetate-acetic acid, pH 5.0 Very broad peak of $\beta$-trypsin

$\mathrm{pH}$ gradient generated by adding $50 \mathrm{~mm}$ sodium acetate, $\mathrm{pH} 4.0$, to $50 \mathrm{~mm}$-sodium cacodylate- $\mathrm{HCl}, \mathrm{pH} 7.0$ then $0.1 \mathrm{M}$-citric acid-1 M-NaCl.

Two gradients generated by adding $50 \mathrm{~mm}$ ammonium formate-formic acid, $\mathrm{pH} 4.0$, to the loading buffer then adding $20 \mathrm{~mm}$ $\mathrm{HCl}$ to the formate buffer, $\mathrm{pH}$ 4.0.
Chromatographic result

$\beta$-Trypsin contaminated with $\alpha$-trypsin

Similar to Fig. 2, but yield of $\beta$-trypsin was low

$\beta$-Trypsin peak contained traces of $\alpha$-trypsin in trailing edge. Citric acid- $\mathrm{NaCl}$ gave a peak containing both $\alpha$ - and $\beta$-trypsin.

Two broad peaks only partially resolved. The first contained both $\alpha$ - and $\beta$-trypsin (pH4.1), the second contained $\beta$-trypsin (pH3.9). 
Table 4. Effect of elution conditions on the resolution of $\alpha$ - and $\beta$-trypsin on $p$-( $p^{\prime}$-phenoxypropoxy)benzamidine-Sepharose conjugate

Loading buffer

$50 \mathrm{~mm}$-Sodium acetate-acetic acid, $\mathrm{pH} 3.5$

50 mM-Sodium acetate-acetic acid, $\mathrm{pH} 4.0$

$50 \mathrm{~mm}$-Sodium acetate-acetic acid, $\mathrm{pH} 4.5$

$50 \mathrm{~mm}$-Sodium acetate-acetic acid, $\mathrm{pH} 5.0$

$50 \mathrm{~mm}$-Sodium acetate-acetic acid, pH4.0 containing $0.5 \mathrm{M}-\mathrm{NaCl}$

$50 \mathrm{M}$-Ammonium formateformic acid, $\mathrm{pH} 4.0$

$50 \mathrm{~mm}-$ Sodium succinate- $\mathrm{HCl}$, pH6.0, containing $10 \mathrm{~mm}-$ $\mathrm{CaCl}_{2}$
Eluting buffer

Loading buffer

Loading buffer

Loading buffer

Loading buffer

Loading buffer

Loading buffer

Loading buffer +1 mM-cetyltrimethyl ammonium bromide

$\mathrm{pH}$ gradient generated by adding $0.2 \mathrm{M}-$ formic acid- $\mathrm{NaOH}, \mathrm{pH} 2.5$, to loading buffer; both buffers contained $0.5 \mathrm{M}$ $\mathrm{NaCl}$
Chromatographic result

Unresolved peak containing inert protein and $\alpha$-trypsin with $\beta$-trypsin in long trailing edge

Similar to Fig. 3

Similar to Fig. 3 but peaks were broader

Peaks were broadened to give a continuum

Similar to that obtained with pH 5.0 buffer

No discrete peak of $\beta$-trypsin

Elution volume of $\alpha$-trypsin decreased

Two incompletely resolved peaks were eluted at $\mathrm{pH} 3.0$ and $\mathrm{pH} 2.8$; the first peak contained $\beta$-trypsin, the other contained a mixture of $\alpha$ - and $\beta$-trypsin phobic character of the spacer arm may cause some of the subsites of the enzyme to be occupied and bring part of the surface of the enzyme into juxtaposition with the support thereby facilitating additional interactions by hydrogen bonding. If so, the differences in chromatographic behaviour of the inhibitor conjugate derived from cellulose and Sepharose can be partially explained. Nevertheless, binding of trypsin presumably involves the active site, since the enzyme can be displaced by the reversible inhibitor, $n$-butylamine.

\section{'Firmly-bound' trypsin}

This description is applied to trypsin which remained bound to conjugates derived from $p-\left(p^{\prime}-\right.$ aminophenoxypropoxy)benzamidine after elution with acetate buffers, pH4.0 or 5.0 , or with $20 \mathrm{~mm}$ butylamine hydrochloride. The retention of some 'firmly bound' trypsin appeared to be independent of the relative amount of $\mathrm{CNBr}$ used to activate the support and of the nature of the support. The 'firmly bound' trypsin was eluted, however, with solutions of citric acid, formic acid or $\mathrm{HCl}$ at $\mathrm{pH} 2$ or with solutions of $n$-butylamine hydrochloride $(\geqslant 0.2 \mathrm{M})$. It always proved to be a mixture of the two forms of trypsin, containing $15-20 \% \alpha$-trypsin. All attempts to resolve the 'firmly bound' $\alpha$ - and $\beta$-trypsin by gradient elution with both $\mathrm{pH}$ gradients and $n$-butylamine concentration gradients were unsuccessful.
We are indebted to the Medical Research Council for a grant to G. W. J.

\section{References}

Axén, R. \& Ernback, S. (1971) Eur. J. Biochem. 18, $351-360$

Baines, N. J., Baird, J. B. \& Elmore, D. T. (1964) Biochem. J. 90, 470-476

Baker, B. R. \& Erickson, E. H. (1968) J. Med. Chem. 11, 245-249

Berezin, I. V., Kazanskaya, N. F. \& Larionova, N. I. (1969) Biokhimiya 35, 983-988

Blumberg, S., Schechter, I. \& Berger, A. (1970) Eur. J. Biochem. 15, 97-102

Chase, T. \& Shaw, E. (1967) Biochem. Biophys. Res. Commun. 29, 508-514

Cuatrecasas, P. (1970) J. Biol. Chem. 245, 3059-3065

Cuatrecasas, P. \& Anfinsen, C. B. (1971a) Methods Enzymol. 22, 345-378

Cuatrecasas, P. \& Anfinsen, C. B. (1971b) Annu. Rev. Biochem. 40, 259-278

Cuatrecasas, P., Wilchek, M. \& Anfinsen, C. B. (1968)

Proc. Nat. Acad. Sci. U.S. 61, 636-643

Cunningham, L. W. (1954) J. Biol. Chem. 211, 13-19

Elmore, D. T., Kingston, A. E. \& Shields, D. B. (1963) J. Chem. Soc. London 2070-2078

Elmore, D. T., Roberts, D. V. \& Smyth, J. J. (1967) Biochem. J. 102, 728-734

Feinstein, G. (1970a) FEBS Lett. 7, 353-355

Feinstein, G. (1970b) Biochim. Biophys. Acta 214, 224 227

Friedberg, F. (1971) Chromatogr. Rev. 14, 121-131 
Gray, W. R. (1967) Methods Enzymol. 11, 469-475

Hartley, B. S. (1970) Biochem. J. 119, 805-822

Hixson, H. F. \& Nishikawa, A. H. (1973) Arch. Biochem. Biophys. 154, 501-509

Hruska, J. F., Law, J. H. \& Kézdy, F. J. (1969) Biochem. Biophys. Res. Commun. 36, 272-277

Inagami, T. (1964) J. Biol. Chem. 239, 787-791

Jameson, G. W. \& Elmore, D. T. (1971) Biochem. J. 124, 66P

Jameson, G. W., Roberts, D. V., Adams, R. W., Kyle, W. S. A. \& Elmore, D. T. (1973) Biochem. J. 131, 107-117

Kasai, K. \& Ishii, S. (1972) J. Biochem. (Tokyo) 71, 363-366

Lowe, C. R. \& Dean, P. D. G. (1971) FEBS Lett. 14, 313-316
O'Carra, P., Barry, S. \& Griffin, T. (1974) Methods Enzymol. in the press

Partridge, M. W. \& Short, W. F. (1947) J. Chem. Soc. London 390-394

Roberts, D. V. \& Elmore, D. T. (1974) Biochem. J. 141, 545-554

Roberts, D. V., Adams, R. W., Elmore, D. T., Jameson, G. W. \& Kyle, W. S. A. (1971) Biochem. J. 123, 41 P-42P

Robinson, N. C., Tye, R. W., Neurath, H. \& Walsh, K. A. (1971) Biochemistry 10, 2743-2747

Rule, N. G. \& Lorand, L. (1964) Biochim. Biophys. Acta 81, 130-135

Schroeder, D. D. \& Shaw, E. (1968) J. Biol. Chem. 243, 2943-2949

Uren, J. R. (1971) Biochim. Biophys. Acta 236, 67-73

Vahlquist, A., Nilsson, S. F. \& Peterson, P.A.(1971) Eur.J. Biochem. 20, 160-168 